\title{
Front Matter: Volume 8593
}

, "Front Matter: Volume 8593," Proc. SPIE 8593, Optical Methods in Developmental Biology, 85930S (3 April 2013); doi: 10.1117/12.2021945

SPIE. Event: SPIE BiOS, 2013, San Francisco, California, United States 


\section{PROGRESS IN BIOMEDICAL OPTICS AND IMAGING}

\section{Optical Methods in \\ Developmental Biology}

Andrew M. Rollins

Cecilia Lo

Scott E. Fraser

Editors

2 February 2013

San Francisco, California, United States

Sponsored by

SPIE

Cosponsored by

Bioptigen (United States)

Published by

SPIE 
The papers included in this volume were part of the technical conference cited on the cover and title page. Papers were selected and subject to review by the editors and conference program committee. Some conference presentations may not be available for publication. The papers published in these proceedings reflect the work and thoughts of the authors and are published herein as submitted. The publisher is not responsible for the validity of the information or for any outcomes resulting from reliance thereon.

Please use the following format to cite material from this book:

Author(s), "Title of Paper," in Optical Methods in Developmental Biology, edited by Andrew M. Rollins, Cecilia Lo, Scott E. Fraser, Proceedings of SPIE Vol. 8593 (SPIE, Bellingham, WA, 2013) Article CID Number.

ISSN: $1605-7422$

ISBN: 9780819493620

Published by

SPIE

P.O. Box 10, Bellingham, Washington 98227-0010 USA

Telephone +1 3606763290 (Pacific Time) · Fax +1 3606471445

SPIE.org

Copyright @ 2013, Society of Photo-Optical Instrumentation Engineers.

Copying of material in this book for internal or personal use, or for the internal or personal use of specific clients, beyond the fair use provisions granted by the U.S. Copyright Law is authorized by SPIE subject to payment of copying fees. The Transactional Reporting Service base fee for this volume is $\$ 18.00$ per article (or portion thereof), which should be paid directly to the Copyright Clearance Center (CCC), 222 Rosewood Drive, Danvers, MA 01923. Payment may also be made electronically through CCC Online at copyright.com. Other copying for republication, resale, advertising or promotion, or any form of systematic or multiple reproduction of any material in this book is prohibited except with permission in writing from the publisher. The CCC fee code is $1605-7422 / 13 / \$ 18.00$.

Printed in the United States of America.

Publication of record for individual papers is online in the SPIE Digital Library.

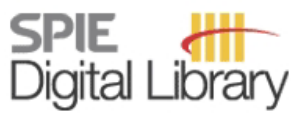

SPIEDigitalLibrary.org

Paper Numbering: Proceedings of SPIE follow an e-First publication model, with papers published first online and then in print and on CD-ROM. Papers are published as they are submitted and meet publication criteria. A unique, consistent, permanent citation identifier (CID) number is assigned to each article at the time of the first publication. Utilization of CIDs allows articles to be fully citable as soon as they are published online, and connects the same identifier to all online, print, and electronic versions of the publication. SPIE uses a six-digit CID article numbering system in which:

- The first four digits correspond to the SPIE volume number.

- The last two digits indicate publication order within the volume using a Base 36 numbering

system employing both numerals and letters. These two-number sets start with 00, 01, 02, 03, 04, $05,06,07,08,09,0 A, 0 B \ldots 0 Z$, followed by 10-1Z, 20-2Z, etc.

The CID Number appears on each page of the manuscript. The complete citation is used on the first page, and an abbreviated version on subsequent pages. Numbers in the index correspond to the last two digits of the six-digit CID Number. 


\title{
Contents
}

\author{
$\checkmark \quad$ Conference Committee
}

\section{SESSION 1 CARDIOVASCULAR DEVELOPMENT I}

859302 High-resolution time-resolved 3D optical microscopy inside the beating zebrafish heart using prospective optical gating [8593-2]

J. M. Taylor, Durham Univ. (United Kingdom) and Glasgow Univ. (United Kingdom);

C. D. Saunter, G. D. Love, J. M. Girkin, Durham Univ. (United Kingdom)

859304 In vivo functional imaging of embryonic chick heart using ultrafast 1310nm-band spectral domain optical coherence tomography [8593-4]

P. Li, Northeastern Univ. at Qinhuangdao (China) and Univ. of Washington (United States);

X. Yin, Univ. of Washington (United States); R. K. Wang, Northeastern Univ. at Qinhuangdao (China) and Univ. of Washington (United States)

859305 Changes in strain and blood flow in the outflow tract of chicken embryo hearts observed with spectral domain optical coherence tomography after outflow tract banding [8593-5] Z. Ma, L. Du, Q. Wang, Z. Chu, X. Zang, F. Wang, Northeastern Univ. at Qinhuangdao (China); R. K. Wang, Univ. of Washington (United States)

\section{SESSION 2 CARDIOVASCULAR DEVELOPMENT II}

859309 Ultra-high frequency ultrasound biomicroscopy and high throughput cardiovascular phenotyping in a large scale mouse mutagenesis screen [8593-9]

X. Liu, R. Francis, K. Tobita, A. Kim, Univ. of Pittsburgh School of Medicine (United States);

L. Leatherbury, Children's National Medical Ctr. (United States); C. W. Lo, Univ. of Pittsburgh School of Medicine (United States)

\section{SESSION 3 WHOLE EMBRYO AND LONGITUDINAL IMAGING}

8593 OA In vivo imaging of zebrafish from embryo to adult stage with optical projection tomography [8593-10]

A. Bassi, L. Fieramonti, C. D'Andrea, G. Valentini, R. Cubeddu, S. De Silvestri, G. Cerullo, Politecnico di Milano (Italy); E. Foglia, F. Cotelli, Univ. degli Studi di Milano (Italy)

8593 OE OCT guided microinjections for mouse embryonic research [8593-14]

K. V. Larin, Baylor College of Medicine (United States) and Univ. of Houston (United States); S. H. Syed, Baylor College of Medicine (United States); A. J. Coughlin, Rice Univ. (United States); S. Wang, Univ. of Houston (United States); J. L. West, Rice Univ. (United States); M. E. Dickinson, I. V. Larina, Baylor College of Medicine (United States) 
8593 Ol Effect of alcohol exposure on fetal brain development [8593-18]

N. Sudheendran, Univ. of Houston (United States); S. Bake, R. C. Miranda, Texas A\&M Health Science Ctr. (United States); K. V. Larin, Univ. of Houston (United States) and Saratov State Univ. (Russian Federation)

\section{SESSION 5 LINEAGE MAPPING, FATE PROFILING, PREGENITOR CELL TRACKING, AND REPRODUCTIVE} BIOLOGY

8593 OK Combined lineage mapping and fate specification profiling with NLOM-OCM using sub-10fs pulses [8593-20]

H. C. Gibbs, C. R. Dodson, Y. Bai, A. C. Lekven, A. T. Yeh, Texas A\&M Univ. (United States)

$8593 \mathrm{OL} \quad$ Motility contrast imaging of live porcine cumulus-oocyte complexes [8593-21]

R. An, J. Turek, Z. Machaty, D. Nolte, Purdue Univ. (United States)

\section{POSTER SESSION}

$8593 \mathrm{ON}$ Computational analysis of the spatial distribution of mitotic spindle angles in mouse developing airway [8593-23]

N. Tang, National Institute of Biological Science (China) and Univ. of California, San Francisco (United States); W. F. Marshall, Univ. of California, San Francisco (United States)

859300 Birefringence analysis of cultured and imitation pearls using polarization-sensitive sweptsource OCT [8593-24]

J. H. Lee, E. J. Min, J. G. Shin, K. S. Park, Gwangju Institute of Science and Technology (Korea, Republic of); H.-Y. Kim, Gyeongsang National Univ. (Korea, Republic of) and Korea Pearl Lab. (Korea, Republic of); B. H. Lee, Gwangju Institute of Science and Technology (Korea, Republic of)

Author Index 


\section{Conference Committee}

Symposium Chairs

James Fujimoto, Massachusetts Institute of Technology

(United States)

R. Rox Anderson, Wellman Center for Photomedicine, Massachusetts General Hospital (United States) and Harvard School of Medicine (United States)

Program Track Chairs

Ammasi Periasamy, University of Virginia (United States)

Daniel L. Farkas, University of Southern California (United States)

\section{Conference Chairs}

Andrew M. Rollins, Case Western Reserve University (United States)

Cecilia Lo, University of Pittsburgh (United States)

Scott E. Fraser, California Institute of Technology (United States)

\section{Conference Program Committee}

Michael A. Choma M.D., Yale School of Medicine (United States)

Anjul M. Davis, Thorlabs Inc. (United States)

Mary Elizabeth Dickinson, Baylor College of Medicine (United States)

Robert G. Gourdie, Virginia Polytechnic Institute and State University (United States)

Michael W. Jenkins, Case Western Reserve University (United States)

Bradley B. Keller, University of Lovisville (United States)

Kirill V. Larin, University of Houston (United States)

Kersti Linask, University of South Florida (United States)

Charles D. Little, The University of Kansas Medical Center (United States)

David Sedmera M.D., Charles University in Prague (Czech Republic)

Ruikang K. Wang, University of Washington (United States)

Michiko Watanabe, Case Western Reserve University (United States)

Talât Mesud Yelbuz, Medizinische Hochschule Hannover (Germany)

\section{Session Chairs}

1 Cardiovascular Development I

Andrew M. Rollins, Case Western Reserve University (United States) 
2 Cardiovascular Development II

Michael A. Choma M.D., Yale School of Medicine (United States)

3 Whole Embryo and Longitudinal Imaging

Cecilia Lo, University of Pittsburgh (United States)

4 Neurological and Respiratory Development

Kirill V. Larin, University of Houston (United States)

$5 \quad$ Lineage Mapping, Fate Profiling, Pregenitor Cell Tracking, and Reproductive Biology

Michael W. Jenkins, Case Western Reserve University (United States) 